\title{
Determinants of Target Capital Structure and Adjustment Speed: Evidence from India
}

\author{
Sutanuka Shaw ${ }^{1, *}$, Debdas Rakshit ${ }^{2}$ \\ ${ }^{1}$ Department of Commerce, T.D.B College, Raniganj, West Bengal, India \\ ${ }^{2}$ Department of Commerce, The University of Burdwan, West Bengal, India \\ Received December 19, 2020; Revised February 3, 2021; Accepted February 27, 2021
}

\begin{abstract}
Cite This Paper in the following Citation Styles
(a): [1] Sutanuka Shaw, Debdas Rakshit, "Determinants of Target Capital Structure and Adjustment Speed: Evidence from India," Universal Journal of Accounting and Finance, Vol. 9, No. 2, pp. 160 - 169, 2021. DOI: 10.13189/ujaf.2021.090203.
\end{abstract}

(b): Sutanuka Shaw, Debdas Rakshit (2021). Determinants of Target Capital Structure and Adjustment Speed: Evidence from India. Universal Journal of Accounting and Finance, 9(2), 160 - 169. DOI: 10.13189/ujaf.2021.090203.

Copyright $\bigcirc 2021$ by authors, all rights reserved. Authors agree that this article remains permanently open access under the terms of the Creative Commons Attribution License 4.0 International License

\begin{abstract}
This paper analyses the adjustment speed of the firm to achieve target leverage. The study further extends the empirical work to diagnose the factors that significantly impact its capital structure. The study consists of 132 Indian non-financial firms listed in the National Stock Exchange for the period 1998-2018. A static panel model and dynamic two-step GMM model has been used to make a comparative analysis and select the best model. The results of the study claim that the adjustment speed is 44 percent per annum, yielding a half-life of 1.18 years. Further, the study reveals that profitability, tangibility, and GDP growth are significantly related to leverage in the dynamic model. In the static model, besides profitability, tangibility, and GDP Growth, its uniqueness, growth, and age also significantly impact leverage. In the study, the $\mathrm{R}$ square appears to be 0.34 , and the determinants, namely, profitability, growth uniqueness, and age, follow pecking order theory, and size, tangibility, liquidity, GDP Growth, and inflation follow trade-off theory. The comparative statement results reveal that the dynamic model is more realistic, considering the adjustment cost. This paper can be further improved by incorporating human resource factors and their impact on its leverage.
\end{abstract}

Keywords Capital Structure, TOT, POT, Determinants, Fixed Effect, Two-Step GMM Model

\section{Introduction}

Since a few decades, capital structure theory has been one of the most controversial issues in corporate finance. The financial managers have always aimed to maximise firm value, and in order to do so, it is important to identify an optimum ratio of debt and equity that would result in the maximisation of shareholders wealth. The controversy regarding the capital structure theories originating from Modigliani and Miller's seminal work, which claimed that the firm's value is independent of its capital structure, i.e. the choice of a combination of debt and equity has no impact on the firm value. Following MM (1958), the capital structure theories became the most contentious issues in the academic arena because capital structure helps to undertake the firms' financing decisions and the other decisions related to the investment and operation of the business depends on the financing decisions. However, the MM proposition was criticised from several angles since it is based on too many assumptions such as no taxes, no transaction costs, no bankruptcy cost and no asymmetric information which made the theory very unrealistic. Bradley et al. (2013) stated that with the incorporation of taxes, MM proposed full financing with debt as it was considered risk-free and had the advantage of the interest tax shield. The "Trade-off" theory later emerged and proposed that the firm's capital structure should constitute an optimum combination of debt and equity by balancing the cost and benefit of debt. Here benefits are referred to the firm's interest tax shield due to debt financing and cost referred to as the bankruptcy cost. So the firms need to maintain a trade-off in order to achieve the optimal capital structure. This optimal capital structure can be achieved by maintaining a balance 
between the cost of capital and the bankruptcy risk. The static trade-off theory supports the idea of optimal capital structure, but the dynamic trade-off theory rejects the same claiming that though firms prefer to achieve the target capital structure, they suffer from deviations due to asymmetric information (Myers,1984; Myers \&Majluf, 1984 ) and market timing perspectives (Baker \&Wurgler, 2002) but they tend to achieve target leverage by increasing or decreasing debt or equity for future for minimising the cost of deviation. Donaldson (1961) proposed the pecking order theory which was modified by Myers and Majluf (1984). They stated that firms tend to follow a hierarchical order of financial choices. According to them, primarily the firm uses retained earnings to fulfil their financial requirement, then debt and lastly equity. Agency cost theory indicates two agency costs: agency cost of debt and agency cost of equity.

However, a very common question regarding the capital structure is whether the firms set a target capital structure and adjust to it? In this respect, the capital structure literature has provided several explanations regarding the determinants of target capital structure and their speed of adjustment using the modern capital structure theories, namely, pecking order theory, trade-off theory, signaling theory and market timing theory. Fisher et al. (1989) formulated the dynamic capital structure model and considered adjustment costs. Since then, the target capital structure has become an important area of research in corporate finance. Flannery and Rangan stated a dynamic partial adjustment model to evaluate the adjustment speed to achieve the target capital structure.

The literature found that there have been many studies in dynamic capital structure and the impact of micro-economic and macro-economic factors on the dynamic capital structure and speed adjustment (Drobetz\&Wanzenried,2006; Guha-Khasnobis\& Bhaduri,2002; Byoun,2008). From the theoretical perspective, all the firms should be maintaining their optimal capital structure. However, in real life market imperfections may deter firms from achieving optimal capital structure. The adjustment process continues while conditions vary. So it is necessary to measure the speed of such adjustment. This research's main motivation is to undertake speed adjustment to achieve the target capital structure of the selected Indian firms. Prior studies reveal that several firms aim to adjust the firm's actual capital structure towards the target to enjoy the benefits of the reduced overall weighted average cost of capital, making risks manageable and leading to its value generation. The present study primarily aims to estimate the adjustment speed at which the firm aims to achieve the target leverage. Secondly, this study aims to identify the factors that significantly influence the capital structure and, thirdly, to make a comparative study about which model gives better results.

\section{Literature Review}

Many studies investigate capital structure theories and various factors affecting the capital structure of the firm. The theory of capital structure was first developed from a modern perspective by Modigliani and Miller. But the conclusion heavily depends on several strict assumptions. Modification emerged later to relax some assumptions. Kraus and Litzenberger (1973) stated optimal capital structure implies trade-off between bankruptcy costs and tax benefits arising out of debt used for a single period. Myers (1977) focused on agency cost of debt, thus showing that if there is a possibility of bankruptcy, even the value-added projects will not provide any incentive to the equity shareholders for further new investments. Ferry and Jones (1979) studied the relationship between the firm's financial structure and four firm-specific factors and provided empirical evidence that firm size and leverage tend to have a curvilinear relationship rather than a positive one and claimed that operating leverage and firm's debt are negatively related. It has been seen that observed capital structures frequently vary from the target capital structures due to adjustment costs. This has been supported by the dynamic trade-off theory (Leary and Roberts, 2005). Using dynamic panel adjustment model, Jooma and Gwatidzo (2013) studied the firm-specific determinants of target capital structure and adjustment speed in four African countries. They found that African firms adjust faster short-term debt targets as they have lower speed of adjustment where the adjustment costs are high, and the capital markets are less developed. Flannery and Rangan (2006) find the adjustment speed to be $34.2 \%$ using book leverage and $35.5 \%$ using market leverage. The study used data of 12,919 financial (SIC 6000 - 6999) and regulated (SIC 4900-4999) enterprises for the period 1965-2001and revealed that the firms do have target capital structures. Fama and French (2002) found the adjustment speed ranging between $7 \%-18 \%$ per year, and this study strongly supports that firms with more investments have less market leverage. Iliev and Welch (2010) used 136,450 firm-year observations for the period 1963-2007 and reported negative speed of adjustment up to $-7 \%$ and provided a reason that managers "amplify the effects of shocks". Their study rejected the null hypothesis of no readjustment, so the firm's observed debt and equity changes should be different from those of the randomly chosen firm. Mwangi, Anyango and Amenya (2012) studied target leverage and speed of adjustment and found that the adjustment speed is $16 \%$ in 23 firms listed in the Nairobi Stock Exchange. Tangkong (2012), in Thailand, uses both one-step and two-step GMM method in a dynamic panel model for determining the speed of adjustment towards target capital structure. Their study's results claim that the firm's leverage is positively related to median industry leverage for 39 Thai companies during 2002-09. Contrarily, Abdeljawad et al. (2013) in their 
study portrays a varied conclusion where the speed of adjustment of the Malaysian firms towards their target is at a slow rate of $12.7 \%$. They also reveal another aspect in their study, which claims that over-leveraged firms can adjust the target capital structure faster than under-leveraged firms because of the asymmetric benefits of being at the target. Nguyen, Ho and Vo (2019)has taken data from Ho Chi Minh Stock Exchange (HOSE) over the period 2008 to 2017 except for firms operating in finance, insurance, and investment sectors. The results reveal that the Vietnamese firms follow the trade-off theory to attain optimal capital structure and tend to substitute debt and equity for attaining target debt ratio. Ramirez, Calvo and Martinez (2017) studied 2093 private Spanish firms over the period 2000-2008 and found that family firms' leverage ratio differs from that of the non-family firms. Small family firms show a negative relationship between growth and debt. Medium and large firms have a negative relationship between cash flow and debt. The static capital structure suffers from several limitations as it does not consider the firm's optimal capital structure about the fluctuation in the value of the assets over time. It leads to the emergence of the dynamic capital structure models that cater to overcoming time-variant limitation.

From the literature, we have found that less works have been done on dynamic capital structure in Indian context regarding speed adjustment and target capital structure. This study wants to fill the gap by analysing the adjustment speed to attain the target capital structure using the dynamic capital structure model. The dynamic theory emphasizes on the significance of time, the role of expectations and adjustment costs (Fisher, Heinkel and Zenchner,1989). Due to asymmetric information in the firm and transaction costs, firms often tend to deviate temporarily from their optimal capital structure. It gives rise to a very eminent question of the adjustment speed to target capital structure.

\section{Variable Description}

PROFITABILITY: Profitability measures the utilisation of total assets which leads to the generation of income. It can be explained in light of both the trade-off theory and the pecking order theory. The trade-off theory predicts a positive relationship between profitability and leverage. It is easy for profitable firms to borrow more debt due to lower risk of distress and interest tax shield leads to a positive relationship of profitability with leverage. Pecking order theory predicts that profitability is negatively related to leverage. So, profitable firms with fixed dividend commitments make less use of debt. On the other hand, less profitable firms tend to use more debt due to the inadequate internal funds. There has been good literature to support a negative relationship between profitability and leverage namely, Wald (1999), Myers
(2001), Fama\& French (2002), Frydenberg (2004), Kayhan\& Titman (2007) and Frank \&Goyal (2009).

\section{H1: Profitability affects target capital structure negatively.}

Size: Size of a firm is measured as a natural log of net sales. According to trade-off theory, firm size is positively related to leverage. It is predicted that larger firms tend to have lower default risk. However, the pecking order theory predicts a negative relationship between the size of a firm and leverage. It claims that larger firms tend to be older and enjoy the benefit of retained earnings, and larger firms with less adverse selection problems can issue equity easily relative to smaller firms. There has been empirical evidence that supports both the theories. Rajan and Zingles (1995), Fama and French (2005), Frank and Goyal (2009) and Baker \& Martin (2011). However, some literature support pecking order theory as well, namely Titman and Wessels (1998).

\section{H2: Size affects the target capital structure negatively.}

Growth: Several studies assume growth is inversely related to leverage which is in line with the trade-off theory. Growth firms have more investment opportunities. However, an increase in borrowings leads to higher financial distress costs, resulting in a fall of optimal ratio. So, the ability to borrow is lessened, leading to a negative relationship between the two. However, pecking order theory suggests a positive relationship between growth and leverage since in times of growth, firms may not be able to finance the projects entirely with internal funds to borrow more. Most literature suggests that this determinant follows the trade-off theory (Myers,1977; Kim and Sorensen, 1986; Rajan and Singles,1995; Frank and Goyal,2009.

\section{H3: Growth affects target capital structure positively.}

Tangibility: A higher proportion of tangible assets claim more security to the creditors since they provide collateral value. The trade-off theory states that there exists a positive relationship between tangibility and leverage. When a company consists of a greater amount of tangible assets, it bears a lower risk of bankruptcy to rely more on debt. It has been agreed by several researchers, Friend and Lang (1988), Rajan and Zingles (1995), Baker and Martin (2011). However, the pecking order theory predicts a negative relationship between the two supported by Harris and Raviv (1995) and Booth et al. (2001).

\section{H4: Tangibility affects target capital structure negatively.}

Non-debt tax shield: Taxation is very closely associated with capital structure. DeAngelo and Masulis (1980) stated that tax deductions that are not related to debt substitutes for interest tax shield. NDTS implies the tax deduction relating to depreciation and tax credits 
relating to the investment. Trade-off theory predicts negative relationship between NDTS and leverage since firms with high NDTS tend to have lower debt ratios. Several empirical studies support this relationship, DeAngelo\&Masulis (1980); Titman \&Wessels (1988); Frydenberg (2004).

\section{H5: Non-debt tax shield affects target capital structure negatively.}

Liquidity: Liquidity is measured as a ratio of current assets to current liabilities. The trade-off theory predicts a positive relationship between leverage and liquidity because high liquidity indicates more leverage since it can meet the short term obligations with the high cash flows (Ross, 1977). However, pecking order theory states a negative relationship between the two because it states that liquid firms tend to use more retained earnings to finance their investment projects. Myers, 1984; Titman \&Wessels, 1988; Rajan\&Zingles, 1995 support the pecking order theory concerning the impact of liquidity on leverage.

\section{H6: Liquidity affects target capital structure negatively.}

Uniqueness: Uniqueness is measured by dividing selling expenses by net sales. Firms producing unique products require to undertake various means of advertisement in order to market the product. According to the pecking order theory, the firm's uniqueness has a significant positive relationship with leverage because selling expenses are directly related to sales, and incurred to mobilise the market. However, the trade-off theory states a negative relationship because it is positively related to non-debt tax shield and inversely related to the assets' collateral value.

\section{H7: Uniqueness affects target capital structure positively.}

AGE OF THE FIRM: The firm's age is a very significant factor that impacts leverage. Older firms with a long history tend to enjoy goodwill and reputation, which helps them obtain more debt. The trade-off theory indicates a positive relationship between age and leverage, while pecking order theory predicts an inverse relationship. The pecking order theory poses that as older firms have large amounts of accumulated retained earnings, instead of borrowing from external sources, firms would prefer to use their internal funds primarily.

\section{H8: Age of the firm affects the target capital structure negatively.}

GDP Growth: GDP Growth in general measures economic growth of the country. Situations of economic growth, characterised by higher share prices and more cash reserves result in non-availability of adequate tangible assets to grab the investment opportunities and materialise them. So, the trade-off theory predicts a negative relationship between GDP Growth and leverage, Kayo \& Kimura (2011); Demirguc-Kunt\&Maksimovic (1996). Contrarily, the pecking order theory proposes a positive relationship between GDP Growth and leverage since it implies that increase in investment opportunities lead to utilisation of internal fund and also a requirement of more external funds in order to finance the new investment projects, Beck et al. (2008), De Jong et al.(2008), Muthuma et al. (2013).

\section{H9: GDP growth affects the target capital structure positively.}

INFLATION: The percentage change in consumer prices measures inflation. Trade-off theory implies that inflation has a positive impact on leverage. During inflation, borrowers tend to gain because they pay a lower amount of real value when they repay their debts. Thus, there exists a positive relationship between inflation and leverage. In their empirical study, Frank \&Goyal (2009) depicted that debt became high in times of high inflation in the US.

\section{H10: Inflation affects the target capital structure} positively.

\section{Database and Methodology}

We considered all the non-financial companies listed in the National Stock Exchange, having an annual turnover of more than 400 crores. Then primarily, we selected 536 Indian firms, but due to non-availability of data and missing figures, the data set has been finally brought down to 132 firms. A balanced panel data set of 132 firms have been considered for 21 years from 1998 to 2018. A considerable amount of long time frame has been taken to study the impact of various factors on capital structure significantly and determine the adjustment speed, at which the firm will move towards the attainment of target leverage. The data has been collected from Capitaline 2000 data package, and the calculations have been done in Stata 14.

\section{Methodology}

In this study, we construct two models. The following model denotes the static panel data, linear regression model. While estimating the model, it is important to diagnose which model is best fit for our analysis. Hausman test is used to select the best model between the random effect model and the fixed-effect model. The Hausman test aims to test whether the error term and the independent variables are correlated in the model. If the error term and the independent variables are uncorrelated, then the random effect model is considered appropriate, 
and if it is found to be correlated, then the fixed effect model is appropriate.

The study has also performed several diagnostic tests before conducting the regression analysis. Levin, Lin and Chu test has been performed to test whether the variables are stationary or not. The static panel data linear regression model is as follows:

Levit $=\beta 0+\beta 1$ PRit $+\beta 2$ SZit $+\beta 3$ GRit $+\beta 4$ TNit $+\beta 5$ NDit $+\beta 6 \mathrm{LQit}+\beta 7 \mathrm{UNit}+\beta 8 \mathrm{AGit}+\beta 9 \mathrm{GDit}+\beta 10 \mathrm{IFit}+\varepsilon \mathrm{i}, \mathrm{t}$

where, $\varepsilon i, t$ denotes the error term. This study's independent variables include profitability, size of the firm, firm growth opportunities, tangibility, non-debt tax shield, liquidity, uniqueness, age of the firm, GDP growth, and inflation.

In the real scenario, the variables are not always exogenous, and there are situations where the past data of the dependent variables have an impact on their present values. So, in these circumstances, it is appropriate to use the dynamic model for analysis, by including a lag of the dependent variable. The dynamic model predicts more realistic results and also controls the endogeneity problem. In this study, the two-step GMM model has been used in order to study the dynamic aspect.

In perfect capital market, firms can have optimum capital structure, but in an imperfect market, the firms cannot maintain the optimum capital structure due to adjustment costs which creates the deviation of actual leverage from the target leverage. So the following model had been developed by Gujarati (2002):

$$
\text { LEVi,t - LEVi,t-1 }=\lambda\left(\mathrm{LEV}^{*} \mathrm{i}, \mathrm{t}-\mathrm{LEVi}, \mathrm{t}-1\right)+\varepsilon \mathrm{e}, \mathrm{t}
$$

This model aims to decrease the gap between the actual leverage and target leverage by $\lambda$.Taking into consideration the actual leverage of the firm, the following value can be generated.

$$
\mathrm{LEVi}, \mathrm{t}=\lambda \mathrm{LEV}^{*} \mathrm{i}, \mathrm{t}+(1-\lambda) \mathrm{LEVi}, \mathrm{t}-1+\varepsilon \mathrm{i}, \mathrm{t}
$$

This model has been framed based on the concept that the various factors that impact capital structure will also influence the target leverage. So, the following equation is formulated:

$$
\mathrm{LEV}^{*} \mathrm{i}, \mathrm{t}=\beta \mathrm{Xi}, \mathrm{t}-1
$$

Where, Xi,t-1 refers to the vector of the various determinants that influence the firm's capital structure. Substituting equation (3) into equation (1), we get the following result:

$$
\text { LEVi,t+1 - LEVi,t }=\lambda(\beta X i, t-L E V i, t)+\varepsilon i, t+1
$$

Resultingly, after further substitution the following models have been developed:

$$
\text { LEVi, } t+1=\lambda \beta X i, t+(1-\lambda) L E V i, t+\varepsilon i, t+1
$$

Now replacing $\mathrm{Xi}$,tby the independent variables we derive the final model for determination of the adjustment speed:

$$
\begin{gathered}
\text { LEVit }=\beta 1 \text { PRit }+\beta 2 \text { SZit }+\beta 3 \text { GRit }+\beta 4 \mathrm{TNit}+\beta 5 \mathrm{NDit}+ \\
\beta 6 \mathrm{LQit}+\beta 7 \mathrm{UNit}+\beta 8 \mathrm{AGit}+\beta 9 \mathrm{GDit}+\beta 10 \mathrm{IFit}+
\end{gathered}
$$$$
(1-\lambda) \mathrm{LEVi}, \mathrm{t}-1+\varepsilon \mathrm{i}, \mathrm{t}
$$

In the dynamic model two diagnostic tests are conducted, namely, Sargan test and Arellano and Bond's (AR1, AR2) test.

\section{Descriptive Statistics}

Table 1 represents the descriptive statistics for all the variables used in the study consisting of 2772 observations. The table depicts that the mean leverage is 0.476 , meaning that the average liabilities contribute to $48 \%$ of the total assets' value for the selected Indian firms. The findings support other Indian literature that more debt is used to meet the financial requirements, Ghose and Kabra, 2017. However, it contradicts with a few other works, which shows a lower debt ratio, Tripathy and Asija, 2017. The mean tangibility is 0.861 which shows that $86.1 \%$ of the Indian sample firms' total assets are fixed assets that can be used as collateral. The mean liquidity is 3.05 , which implies that firms have the power to repay their debt obligation for a short period with the use of current assets. The mean growth is 15.33 , with the high fluctuation showing that Indian firms in the sample tend to expect high future growth.

Table 1. Summary statistics of the dependent and the independent variables

\begin{tabular}{|c|c|c|c|c|c|}
\hline Variable & Observation & Mean & Std.Dev. & Min & Max \\
\hline PR & 2772 & .139 & .139 & -2.7 & 1.17 \\
\hline SZ & 2772 & 6.620 & 1.529 & 2.65 & 11.29 \\
\hline GR & 2772 & 15.327 & 40.419 & -118.34 & 1090.23 \\
\hline TN & 2772 & .861 & .469 & -8.42 & 5.82 \\
\hline ND & 2772 & .045 & .028 & -.43 & .33 \\
\hline LQ & 2772 & 3.051 & 3.071 & .1 & 71 \\
\hline UN & 2772 & .099 & .279 & -.06 & 9.304 \\
\hline AG & 2772 & 3.457 & .557 & 1.386 & 4.942 \\
\hline GD & 2772 & 6.714 & 1.663 & 3.087 & 8.85 \\
\hline IF & 2772 & 6.609 & 3.043 & 2.49 & 13.231 \\
\hline LEV & 2772 & .476 & .313 & -2.21 & 4.15 \\
\hline
\end{tabular}


Table 2. Matrix Correlation

\begin{tabular}{|c|c|c|c|c|c|c|c|c|c|c|}
\hline \multicolumn{11}{|c|}{ Matrix Correlation } \\
\hline & $\mathrm{PF}$ & SZ & GR & $\mathrm{TN}$ & ND & LQ & UN & $\mathrm{AG}$ & GD & IF \\
\hline PR & 1.00 & & & & & & & & & \\
\hline $\mathrm{SZ}$ & 0.10 & 1.00 & & & & & & & & \\
\hline GR & 0.14 & -0.04 & 1.00 & & & & & & & \\
\hline $\mathrm{TN}$ & -0.11 & 0.03 & -0.13 & 1.000 & & & & & & \\
\hline ND & -0.02 & 0.08 & -0.12 & 0.753 & 1.000 & & & & & \\
\hline LQ & -0.13 & -0.26 & 0.02 & -0.127 & -0.076 & 1.00 & & & & \\
\hline UN & 0.01 & 0.01 & -0.02 & 0.029 & 0.105 & -0.06 & 1.00 & & & \\
\hline AG & -0.02 & 0.46 & -0.08 & -0.015 & -0.062 & -0.14 & 0.254 & 1.00 & & \\
\hline GD & 0.04 & 0.11 & 0.03 & 0.017 & 0.005 & -0.03 & 0.006 & 0.082 & 1.00 & \\
\hline $\mathrm{IF}$ & 0.04 & 0.10 & 0.06 & -0.023 & -0.053 & -0.017 & -0.043 & 0.023 & -0.04 & 1.00 \\
\hline
\end{tabular}

Table 3. Multi-collinearity test: Variance Inflation Factor test

MULTICOLLINEARITY TEST : VIF TEST

\begin{tabular}{|c|c|c|c|c|c|c|c|c|c|c|}
\hline Measure & PF & SZ & GR & TN & ND & LQ & UN & AG & GD & IF \\
\hline $\begin{array}{c}\text { Tolerance } \\
\text { value }\end{array}$ & 0.931 & 0.713 & 0.951 & 0.408 & 0.407 & 0.893 & 0.976 & 0.761 & 0.981 & 0.976 \\
\hline VIF & 1.07 & 1.40 & 1.05 & 2.45 & 2.45 & 1.12 & 1.02 & 1.31 & 1.02 & 1.02 \\
\hline
\end{tabular}

Table 2 shows Pearson's Matrix correlation of all the independent variables. The correlation matrix implies that the degree of relationship among the explanatory variables is mostly low, except NDTS and tangibility, which has a correlation coefficient of 0.753 . So, there is a need to verify whether there is any existence of multicollinearity problem.

In order to test for multicollinearity, Variance Inflation Factor test is used. As per Gujarati (2003), if the VIF values of the variables are greater than 10 , it hints at the existence of a multicollinearity problem. However, from the given table, we find that no multicollinearity problem exists.

Table 3. Unit root test

\begin{tabular}{|c|c|c|}
\hline & \multicolumn{2}{|c|}{ Levin, Lin \&Chut } \\
\hline Variable & Statistic & Significance level \\
\hline LEV & -5.473 & 0.000 \\
\hline PR & -9.163 & 0.000 \\
\hline SZ & -5.784 & 0.000 \\
\hline GR & -13.784 & 0.000 \\
\hline TN & -5.492 & 0.000 \\
\hline ND & -7.617 & 0.000 \\
\hline LQ & -11.666 & 0.000 \\
\hline UN & -7.231 & 0.000 \\
\hline AG & -56.289 & 0.000 \\
\hline GD & -24.565 & 0.000 \\
\hline IF & -2.967 & 0.000 \\
\hline
\end{tabular}

Before model estimation and hypothesis testing, it is essential to conduct a Stationary test. This study uses
Levin, Lin Chu test, where the null hypothesis implies that panels containing unit roots and alternative hypothesis show that they are stationary. As panel data consider both time series and cross-section, checking the time element part on the data set stationary test is required. In case there is a presence of unit root in Panel data, the regression results will be spurious, making the mean value of the data set less representative. From the table, all the variables are stationary at levels except inflation which is stationary at the first difference, having significance levels at less than $5 \%$, thus rejecting the null hypothesis. Before doing the regression analysis, several tests were conducted to check the reliability of the data. It is concluded that there lies no multicollinearity problem with the data, and the variables are stationary. All the variables show a long-run equilibrium among themselves as they prove to be co-integrated, and the standard errors are made robust to eliminate the bias and minimize heteroskedasticity problem. So, it can be concluded that the data set is appropriate for running the regression analysis.

Table 4. Hausmantest

\begin{tabular}{|c|c|c|}
\hline \multicolumn{3}{|c|}{ Hausman Specification Test } \\
\hline F statistics & Significance level & Results \\
\hline 141.38 & 0.000 & Fixed Effect \\
\hline
\end{tabular}

It is essential to select the best model between the fixed effect model and random effect model. The best model is selected using the Hausman test. The Hausman test results show that the F statistics is 141.38 with a p-value of 0.000 , which is less than 0.05 , implying the null hypothesis's rejection. Thus, the model's result states that the fixed effect model is most appropriate for this study. 
Table 5. Determinants of the capital structure of the selected Indian companies listed in National Stock Exchange

\begin{tabular}{|c|c|c|c|}
\hline $\begin{array}{c}\text { Estimating } \\
\text { Model }\end{array}$ & \multicolumn{3}{|c|}{ Fixed Effect Model } \\
\hline $\begin{array}{c}\text { Dependent } \\
\text { Variable }\end{array}$ & \multicolumn{2}{|c|}{ LEVERAGE (Total Debt Ratio) } \\
\hline $\begin{array}{c}\text { Independent } \\
\text { Variable }\end{array}$ & Coefficient & t-statistic & Significance level \\
\hline PR & -0.718 & -20.95 & $0.00^{* * *}$ \\
\hline SZ & 0.038 & 4.10 & $0.00^{* * *}$ \\
\hline GR & 0.000 & 4.03 & $0.00^{* * *}$ \\
\hline TN & 0.149 & 8.36 & $0.00^{* * *}$ \\
\hline ND & 1.292 & 4.46 & $0.00^{* * *}$ \\
\hline LQ & 0.003 & 1.82 & 0.07 \\
\hline UN & 0.128 & 7.91 & $0.00^{* * *}$ \\
\hline AG & -0.214 & -5.91 & $0.00^{* * *}$ \\
\hline GD & -0.005 & -1.94 & $0.05^{* *}$ \\
\hline IF & 0.003 & 2.07 & $0.04 * *$ \\
\hline Cons. & 0.860 & 10.87 & $0.00^{* * *}$ \\
\hline $\begin{array}{c}\text { Adjusted } \\
\text { R-square }\end{array}$ & 0.338 & & \\
\hline F statistic & 91.98 & & \\
\hline $\begin{array}{c}\text { Sig (F } \\
\text { statistic) }\end{array}$ & 0.000 & & \\
\hline Tic & & & \\
\hline F & & & \\
\hline
\end{tabular}

Table 5 shows the impact of various microeconomic and macroeconomic factors on the selected Indian firms' leverage. Based on the estimated regression coefficient, the firm's profitability tends to negatively impact leverage supported by the pecking order theory of capital structure. This finding is consistent with the studies of Frank and Goyal (2009), Titman \&Wessels (1998), Rajan \&Zingles (1995), Frydenberg (2004) and Kayhan \& Titman (2007). According to the pecking order theory, firms prefer internal funds compared to the external funds. So, considering the investment opportunities fixed, more profitable firms tend to have less debt over the years. The model implies that the firm's size positively impacts firm leverage at a $1 \%$ significance level. This practical implication is in line with the trade-off theory. The trade-off theory claims that larger firms tend to be more diversified on the one hand and have fewer possibilities of bankruptcy. So, it is easy for large firms to rely on more debt. The estimated regression coefficient of size being positive is in line with many kinds of research, Rajan\&Zingles (1995), Frank and Goyal (2009), Ozkan (2001), Sogorb-Mira (2005) and Gaud et al. (2005). The firm's growth is positively related to total debt at a $1 \%$ significance level, following the pecking order theory of capital structure. The pecking order theory claims that firms with greater growth prospects tend to earn more profits and enjoy higher returns. This study's findings are in line with several previous research types claiming a positive relationship between growth and leverage, Zeitun and Tian (2007), Margaritis and Psillaki (2010). Frydenberg (2004) studied that there exists a significant positive relationship between growth and short term debt. Considering tangibility as one of the factors affecting firm leverage, it is found that tangibility has a significant positive relationship with a regression coefficient of 0.149 at $1 \%$ level of significance which implies that it follows the trade-off theory. It is consistent with the findings of many previous pieces of research of Rajan\&Zingles (1995), Shyam Sunder \& Myers (1999), Frank \&Goyal (2009), Jensen, Solberg and Zom (1992). Firms having a greater amount of tangible assets have lower chances of financial distress. The positive significant regression coefficient of Indian firms implies that the tangible assets are often used as collaterals to get loans. So firms with higher tangible assets are in a better position to raise loan capital. Non-debt tax shield also has a significant positive relationship with leverage having a regression coefficient of 1.292. It is mainly because Indian firms tend to rely more on debt to acquire assets to enjoy tax advantage from depreciation. Thus, more acquisition of assets leads to more leverage. DeAngelo and Masulis (1980) stated that NDTS is supposed to have a negative relationship with debt as it is considered a substitute for the tax advantage of leverage. So higher NDTS would lead to lower debt. In Indian firms, NDTS shows a positive relationship, whereas Titman and Wessels (1988) found an insignificant relationship between NDTS and firm leverage.

Liquidity implies a positive regression coefficient of 0.003 at $10 \%$ significance level, which tends to follow the static trade-off theory of capital structure. Uniqueness shows a significant positive relationship with leverage with a coefficient of 0.128 , following the capital structure's pecking order theory. Firms with comparatively more unique products require more sales promotion through advertisement or other promotional techniques to make the product marketable. Uniqueness is expected to be positively related to leverage. Apart from a few microeconomic determinants, we have considered two macroeconomic factors: GDP Growth and inflation. GDP Growth tends to have a statistically significant negative relationship with leverage following the trade-off theory. By GDP Growth, we mean the opportunities available to firms. In a situation where there are several investment opportunities available in a business environment. However, compared to the opportunities, there are inadequate amounts of tangible assets, leading to a loss of value in distress situations. It particularly causes a negative relationship between GDP Growth and leverage, as proposed by the Trade-off theory. It is supported by previous literature of Demirguc and Maksimovic (1996). Inflation also portrays a significant positive relationship with leverage. 
Table 6. Determinants of the capital structure and their expected impact and actual impact according to the two major capital structure theory in modern times:

\begin{tabular}{|c|c|c|c|}
\hline Dependent Variable & \multicolumn{2}{|c|}{ Leverage } & Actual Impact \\
\hline $\begin{array}{c}\text { Independent } \\
\text { Variable }\end{array}$ & Trade off theory & Pecking order theory & \\
\hline Profitability (PR) & + & - & - \\
\hline Size (SZ) & + & + & + \\
\hline Growth (GR) & - & - & + \\
\hline Tangibility (TN) & + & - & + \\
\hline Non debt tax shield (ND) & - & + & + \\
\hline Liquidity (LQ) & - & - & + \\
\hline Uniqueness (UN) & + & + & - \\
\hline Age of business (AG) & - & & + \\
\hline GDP Growth (GD) & + & & + \\
\hline Inflation (IF) & & & + \\
\hline
\end{tabular}

Table 7. Adjustment speed of capital structure of the selected Indian companies listed in the National Stock Exchange

\begin{tabular}{|c|c|c|c|c|c|c|}
\hline \multirow[b]{2}{*}{ Variable } & \multicolumn{3}{|c|}{ Static Panel Model } & \multicolumn{3}{|c|}{ Dynamic Panel Model } \\
\hline & Coefficient & t-statistic & Sig.level & Coefficient & t-statistic & $\begin{array}{c}\text { Significance } \\
\text { level }\end{array}$ \\
\hline LEVt-1 & & & & 0.557 & 3.94 & $0.000 * *$ \\
\hline PR & -0.719 & -12.24 & $0.000 * *$ & -0.645 & -8.10 & $0.000 * *$ \\
\hline SZ & 0.038 & 1.71 & $0.090 *$ & 0.028 & 1.19 & 0.236 \\
\hline GR & 0.000 & 2.95 & $0.004 * *$ & 0.001 & 1.23 & 0.220 \\
\hline $\mathrm{TN}$ & 0.149 & 2.15 & $0.034 * *$ & 0.184 & 2.81 & $0.005 * *$ \\
\hline ND & 1.292 & 1.21 & 0.229 & 0.054 & 0.12 & 0.901 \\
\hline LQ & 0.003 & 0.65 & 0.516 & 0.001 & 0.57 & 0.569 \\
\hline UN & 0.128 & 4.45 & $0.000 * *$ & 0.017 & 0.26 & 0.796 \\
\hline $\mathrm{AG}$ & -0.214 & -2.42 & $0.017 * *$ & -0.161 & -1.63 & 0.104 \\
\hline GD & -0.005 & -2.57 & $0.011 * *$ & -0.005 & -3.70 & $0.000 * *$ \\
\hline IF & 0.003 & 1.42 & 0.157 & -0.000 & -0.31 & 0.753 \\
\hline Cons. & 0.860 & 4.42 & $0.000 * *$ & 0.519 & 2.04 & $0.041 * *$ \\
\hline Observations & 2772 & & & 2640 & & \\
\hline R Square & 0.34 & & & & & \\
\hline Wald $\chi^{2}$ & & & & 364.98 & & 0.000 \\
\hline Sargan Test $(\chi 2)$ & & & & 49.254 & & 0.086 \\
\hline AR (1) & & & & & -2.1441 & 0.0320 \\
\hline $\mathrm{AR}(2)$ & & & & & -1.4166 & 0.1566 \\
\hline
\end{tabular}

Table 7 compares the static panel linear regression model under fixed effects made robust and the dynamic panel model. The dynamic model incorporates the lagged dependent variable, which is significant at $1 \%$ level, with a positive regression coefficient of 0.557 . The two-step system GMM method has been used in case of the dynamic model. Under the dynamic model, it is found that profitability, tangibility and GDP Growth is significantly related to leverage whereas in the static model, besides profitability, tangibility and GDP Growth, uniqueness, growth and age of the firm also appears to be significantly related to leverage. The $\mathrm{R}$ square appears to be 0.34 , stating that the variables' explanatory power is $34 \%$. The
Sargan test results show the p-value is 0.086 , which accepts the null hypothesis satisfying that the over identifying restrictions are valid. The table depicts that profitability negatively impacts the firm's capital structure in both models, which follows the pecking order theory. Size of the firm is significant at $10 \%$ level in the static panel linear regression model, and its size is positively related to leverage following the trade-off theory. The firm's growth opportunities also show a positive relationship with the debt ratio, which is significant at $1 \%$ level following the pecking order theory. Tangibility is considered a very important factor that is impacting the capital structure of the selected Indian firms. It also shows 
a significant positive relationship with leverage following the predictions of trade-off theory. Uniqueness shows a significant positive relationship with leverage at $1 \%$ level, thus following the pecking order theory whereas, age of the firm shows a negative relationship with the total debt ratio. From the macroeconomic perspective, GDP Growth is considered an important factor for determining the target capital structure and the table portrays that GDP Growth is negatively related to leverage which tends to follow the trade-off theory.

Concerning the two-step GMM model, the value of the Wald $\chi 2$ appears to be significant at $1 \%$ level, thus portraying that the model has been accurately specified. The results of Arellano and Bond's (AR1, AR2) test states whether there exists an autocorrelation problem. AR1 depicts first-order serial correlation, and AR2 depicts second-order serial correlation. The study results depict that the p-value of AR1 is 0.03 which is less than 0.05 which implies that there is a serial correlation in the first order, but the p-value of AR2 is 0.156 which is greater than 0.05 , implying that there is no serial correlation of second order. The dynamic model results conclude that the model specified in this study is correct and consistent with the GMM theory's assumption. Due to the adjustment costs in an imperfect market, there emerges the concept of adjustment speed at which the firm urges to achieve the target. In the present study, the speed of adjustment is $44 \%$. The previous literature relating to adjustment speed shows that the countries belonging to the developed world have a lower adjustment speed. The US reported the adjustment speed of 25\% (Lemmon et al. 2008), 23\%- 25\% (Faulkender et al. 2012). One study showed that Malaysian firms have an adjustment speed of $28 \%$ (Ebrahim et al. 2014).

Several relevant kinds of literature provide strong evidence that an increase in debt results in a decrease in the firm's adjustment speed. In the Indian scenario cost of debt is generally lower than the cost of equity due to tax shield as per the Indian income tax laws. In their study, Yang et al. (2019) revealed that the speed of adjustment was $36.7 \%$ when the Chinese firms' average leverage was 0.488 . Several developed countries' studies reveal that the speed of adjustment is nearly $28 \%$ to $30 \%$. In such a situation, it becomes easy to achieve the target capital structure and also the shareholder's ownership remains intact. In our present study, the speed of adjustment is $44 \%$. However, if this can decrease, it would be easier for the firms to achieve the target capital structure.

\section{Conclusions}

This paper investigates various microeconomic and macroeconomic factors that have a remarkable impact on selected Indian firms' capital structure. This study's primary objective is to investigate the factors and then estimate the adjustment speed at which firms move towards the target. From the above analysis, the present study concludes that concerning the selected Indian firms the adjustment speed is $44 \%$ per annum, yielding a half-life of 1.18 years which claims that the time needed to bridge the gap between the actual and the target leverage ratio by $50 \%$ is 1.18 years. The study's findings depict that the dynamic model is more realistic than the static panel model considering the adjustment costs. The study results ultimately state that profitability and tangibility are the most significant microeconomic factors, and GDP Growth is the most significant macro-economic factor that influences the firms' capital structure decision. We believe our paper has contributed to the firms' capital structure decision-making by analysing different factors and their effects on leverage. However, one of our study's limitations is that besides analysing the microeconomic and macroeconomic factors, we could have further considered few human resource factors that significantly impact the firm leverage. After making a critical analysis of the results, we would like to throw light on the firms' policy implication. To achieve the target capital structure, the firms need to increase the portion of leverage, leading to a decrease in adjustment speed. This increase in debt should be in such a manner so that the risk is affordable, and from the controlling aspect, the ownership of the shareholders remain intact. Ultimately the firm can generate value for the organization. A higher amount of speed of adjustment restrains the firms from achieving the target capital structure. Further, we can also compare India with China based on institutional factors such as financial market condition, banking reforms, legal issues, taxation issues, foreign trade policy etc. which can provide a new dimension to understand the capital structure decision and the factors that have a considerable impact on both Indian and Chinese firms. The two countries' development stage may also be a key factor influencing listed firms' capital structure.

\section{REFERENCES}

[1] Arrelano, M., and S. Bond, 1991, Some Tests for Panel Data: Monte Carlo Evidence and an Application to Employment Equations, Review of Economic Studies 58, 277-297.

[2] Bastos, D. D., Nakamura, W. T., \& Basso, L. F. C., (2009), Determinants of capital structure of publicly-traded companies in Latin America: the role of institutional and macroeconomic factors, Journal of International Finance and Economics, Vol. 9, no. 3, pp. 24-39.

[3] Bokpin, G. A., (2009), Macroeconomic development and capital structure decisions of firms: evidence from emerging market economies, Studies in Economics and Finance, Vol. 26, no. 2, pp. 129-142. http://dx.doi.org/10.1108/10867370 910963055 
[4] Booth, L., Aivazian, V., Demirgüç-Kunt, A., \&Maksimovic, V. (2001). Capital structures in developing countries. The Journal of Finance, 56(1), 87-130.

[5] Bradley, M., G. Jarrell, and E. Kim (1984), 'On the Existence of an Optimal Capital Structure: Theory and Evidence', Journal of Finance, 39, 857-928.

[6] Byoun, S. (2008). How and when do firms adjust their capital structures toward targets? The Journal of Finance, 63(6), 3069-3096.

[7] Camara, O., (2012), Capital structure adjustment speed and macroeconomic conditions: U.S. MNCs and DCs, International Research Journal of Finance and Economics, Vol. 84, pp. 106-120.

[8] Daskalakis, N. \& Psillaki, M., (2008), Do country or firm factors explain capital structure? Evidence from SMEs in France and Greece, Applied Financial Economics, Vol. 18, no. 1, pp. 87-97. http://dx.doi.org/10.1080/0960310060101 8864

[9] De Miguel, A., and J. Pindado, 2001, Determinants of the Capital Structure: New Evi- dence from Spanish Data, Journal of Corporate Finance 7, 77-99.

[10] Driffield, N., V. Mahambare, and S. Pal, 2005, Dynamic adjustment of corporate leverage: Is there a lesson to learn from the recent Asia crisis? Working Paper, Aston Business School, England.

[11] Drobetz W. and R. Fix, 2003, What are the Determinants of the Capital Structure? Some Evidence for Switzerland, forthcoming: Swiss Journal of Economics and Statistics.

[12] Ebrahima, M.S., Girma, S., Shah, M.E. \& Williams, J. (2014). Dynamic capital structure and political patronage: The case of Malaysia, International Review of Financial Analysis, 31, pp. 117-128.

[13] Fama, E., and K. French, 2002, Testing Tradeoff and Pecking Order Predictions about Dividends and Debt, Review of Financial Studies 15, 1-33.

[14] Fischer, E., R. Heinkel, and J. Zechner, 1989, Dynamic Capital Structure Choice: The- ory and Tests, Journal of Finance 44, 19-40.

[15] Flannery, M.J., Hankins, K.W., 2007. A Theory of Capital Structure Adjustment Speed. Working Paper, University of Florida.

[16] Flannery, M.J., Hankins, K.W., 2011. Estimating Dynamic Panel Models in Corporate Finance. Working Paper, University of Florida and University of Kentucky.

[17] Flannery, M.J., Rangan, K.P., 2006. Partial Adjustment towards Target Capital Structures. Journal of Financial Economics 79, 469-506.

[18] Friend, I., \& Lang, L.H. (1988). An empirical test of the impact of managerial self-interest on corporate capital structure. The Journal of Finance, 43(2), 271-281.
[19] Harris, M., and A. Raviv, 1991, The Theory of the Capital Structure, Journal of Finance 46, 297-355.

[20] Heshmati A., 2001, The Dynamics of Capital Structure: Evidence from Swedish Micro and Small Firms, Research in Banking and Finance, 2, 199-241.

[21] Jensen, M., 1986, Agency Cost of Free Cash Flows, Corporate Finance and Takeovers, American Economic Review 76, 323-339.

[22] Keshtkar, R., Valipour, H. \& Javanmard, A., (2012), Determinants of corporate capital structure under different debt maturities: empirical evidence from Iran, International Research Journal of Finance and Economics, Vol. 90, pp. $46-53$.

[23] Kouki, M. \& Said, H. B., (2012), Capital structure determinants: new evidence from French panel data, International Journal of Business and Management, Vol. 7, no. 1, pp. 214-229.

[24] Kraus, A., \& Litzenberger, R.H. (1973). A state-preference model of optimal financial leverage. Journal of Finance, 28(4), 911-922.

[25] La Rocca, M., La Rocca, T., Gerace, D., Smark, C., (2009), Effect of diversification on capital structure. Accounting Finance, Vol. 49, no. 4, pp. 799-826. Lim M, T. C. (2012). Determinants of capital structure: empirical evidence from financial services listed firms in China, International Journal of Economics and Finance, Vol. 4, no. 3, pp. 191- 203.

[26] Leary, M.T., \& Roberts, M.R. (2010). The pecking order, debt capacity, and information asymmetry. Journal of Financial Economics, 95(3), 332-355.

[27] Modigliani, F., and M. Miller, 1958, The Cost of Capital, Corporation Finance and the Theory of Investment, American Economic Review 48, 261-297.

[28] Myers, S., 1977, The Determinants of Corporate Borrowing, Journal of Finance 32, 147-175.

[29] Nguyen, Tho and Wu, Jian, (2011), Capital Structure Determinants and Convergence (January 6, 2011). Bankers, Markets and Investors, forthcoming, available online at SSRN: https://ssrn.com/abstract=1735804

[30] Titman, S., and R. Wessels, 1988, The Determinants of Capital Structure Choice, Jour- nal of Finance 43, 1-19.

[31] Tong, G., \& Green, C. J. (2005). Pecking order or trade-off hypothesis? Evidence on the capital structure of Chinese companies . Applied Economics , 37(19), 2179-2189.

[32] Yang, B. (2013). Dynamic capital structure with heterogeneous beliefs and market timing. Journal of Corporate Finance, 22(2), 254-277

[33] Yang, H., Meysami, M. and Meisami, A. (2017). A Rising Market and Capital Structure Decisions, Universal Journal of Accounting and Finance 5(4): 102-108, 2017. DOI: 10.13189/ujaf.2017.050404 